\title{
Dr. Samuel Easton McManis (孟滿秀, 1891-1952), A Missionary Who Brought Together Preventive Medicine and Medical Evangelism
}

\author{
Sung Ku Ahn', Sang Baek Koh², Solam Lee ${ }^{1,2}$, and Jong Won Yoon ${ }^{3}$ \\ Departments of ${ }^{1}$ Dermatology and ${ }^{2}$ Preventive Medicine, Yonsei University Wonju College of Medicine, Wonju; \\ ${ }^{3}$ Purchasing and Property Management Team, Wonju Severance Christian Hospital, Wonju, Korea.
}

\section{THE PATH}

Dr. Samuel Easton McManis was born in Winchester, Ohio (1891), and he graduated from the Ohio Wesleyan University (1920) and the University of Cincinnati College of Medicine (1924). He interned at St. Mary's Hospital from January to August 1924. He married Marion Elizabeth (M.E.) Wallace in January 1924, and moved from San Francisco to Korea on August 30, 1924. His tenure at the Swedish Methodist Hospital of Wonju began on February 23, 1925 and ended in August 1929. ${ }^{1}$ Thereafter, Dr. McManis returned to the United States (US) for a sabbatical. During this period, he studied surgery at a medical school in Pennsylvania. His return to Korea was canceled due to personal reasons. Then, Dr. McManis was laid to rest in New York on December 7, 1952. His wife, M.E. McManis (née Wallace), graduated from the Christ Hospital School of Nursing in 1924. With her husband, she served in Wonju as a public health practitioner and childcare worker between 1924 and 1929 (Fig. 1).

\section{FROM THE UNITED STATES TO JOSEON}

Dr. McManis was mostly trained in his homeland, except for a year spent at the University of Montpellier (France) in 1919. During his college years, McManis joined the Student Volunteer Movement for Foreign Missions, which was part of the

Received: April 24, 2020 Accepted: April 27, 2020

Corresponding author: Sung Ku Ahn, MD, PhD, Department of Dermatology, Yonsei University Wonju College of Medicine, 20 Ilsan-ro, Wonju 26426, Korea. Tel: 82-33-741-0621, Fax: 82-33-748-2650, E-mail: ahnsk@yonsei.ac.kr

(C) Copyright: Yonsei University College of Medicine 2020

This is an Open Access article distributed under the terms of the Creative Commons Attribution Non-Commercial License (https://creativecommons.org/licenses/ by-nc/4.0) which permits unrestricted non-commercial use, distribution, and reproduction in any medium, provided the original work is properly cited.
New York-based International Medical Missionary Society that trained medical missionaries.

McManis' early letters with missionaries indicate that he wanted to be assigned to China. Oliver R. Avison, the head of Severance Hospital at that time, was on a sabbatical in the United States. Hence, McManis asked Avison for advice regarding medical missionary work in Joseon (modern day Seoul) and the equipment required to open a hospital there (June 1924). After overcoming hardships, McManis eventually was named as a medical missionary worker of the Methodist Episcopal Church, and he traveled from San Francisco to Wonju on the USS Van Buren on August 30, 1924. His duties encompassed various roles, including missionary work, education, and medical care.

\section{COMBINING MEDICAL MISSIONARY WORK WITH PREVENTIVE MEDICINE}

The Swedish Methodist Hospital (Fig. 2) re-opened in February 1925, thanks to the proactive efforts of a medical missionary worker named Anderson. ${ }^{2}$ The closure of the hospital turned out to be a blessing in disguise, as the people of the area began to appreciate the hospital more in its absence. For a short period after its re-opening, the hospital only offered out-patient treatments due to the time required to train assistants and nurses required to operate the hospital.

Moreover, the high number of patients necessitated the hosting of patients in houses near the hospital and required that medical staff visit those houses to administer treatment. On average, the hospital treated 20 patients per day (Table 1). A patient waiting for treatment described their experience by saying, "We await the medical missionary workers like children waiting for their parents." From 1925 to 1929, Sa Young $\mathrm{Ahn}^{3}$ and Eun-gye Lee (two doctors trained in Severance Hos- 

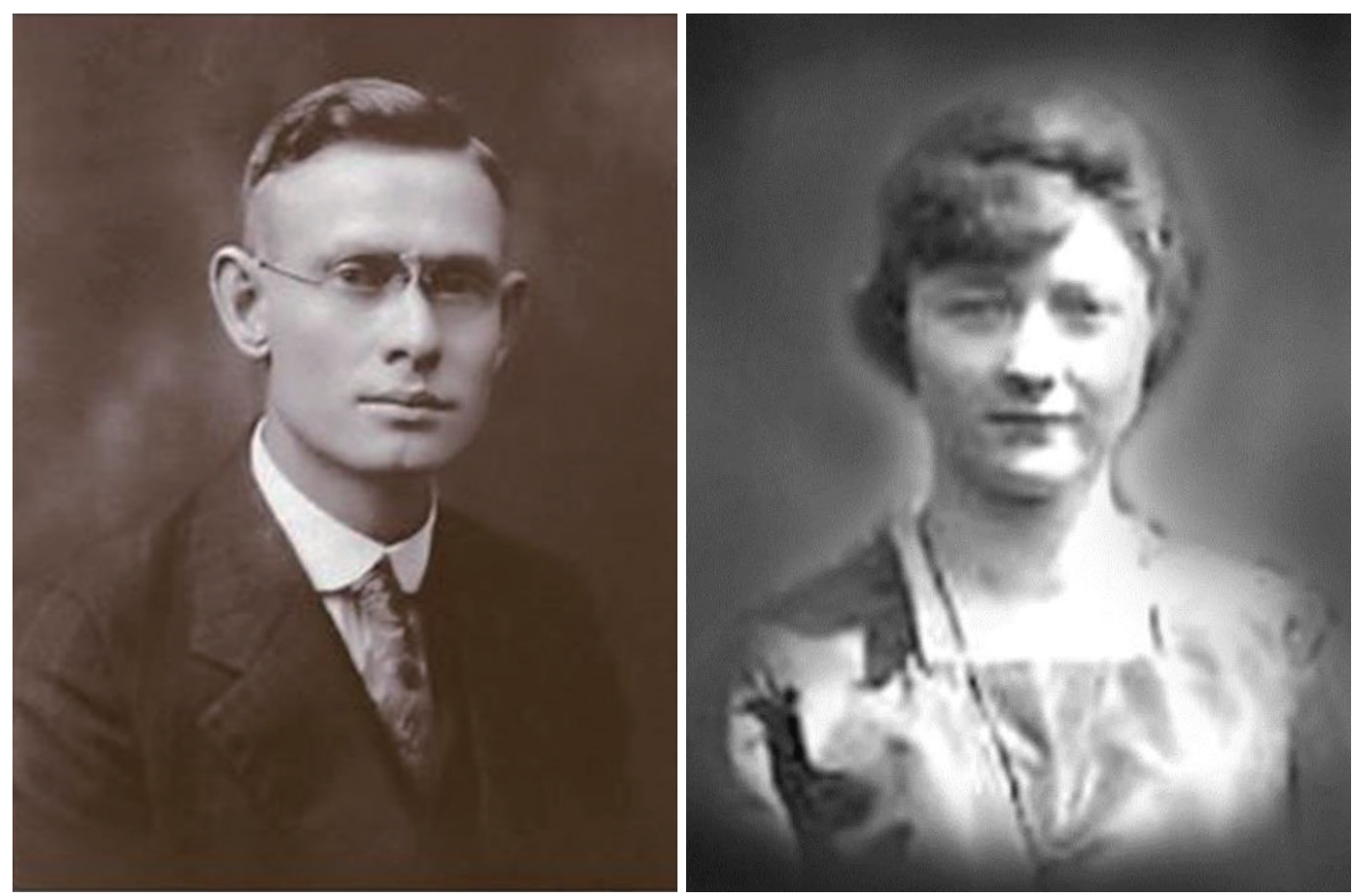

Fig. 1. McManis couple.
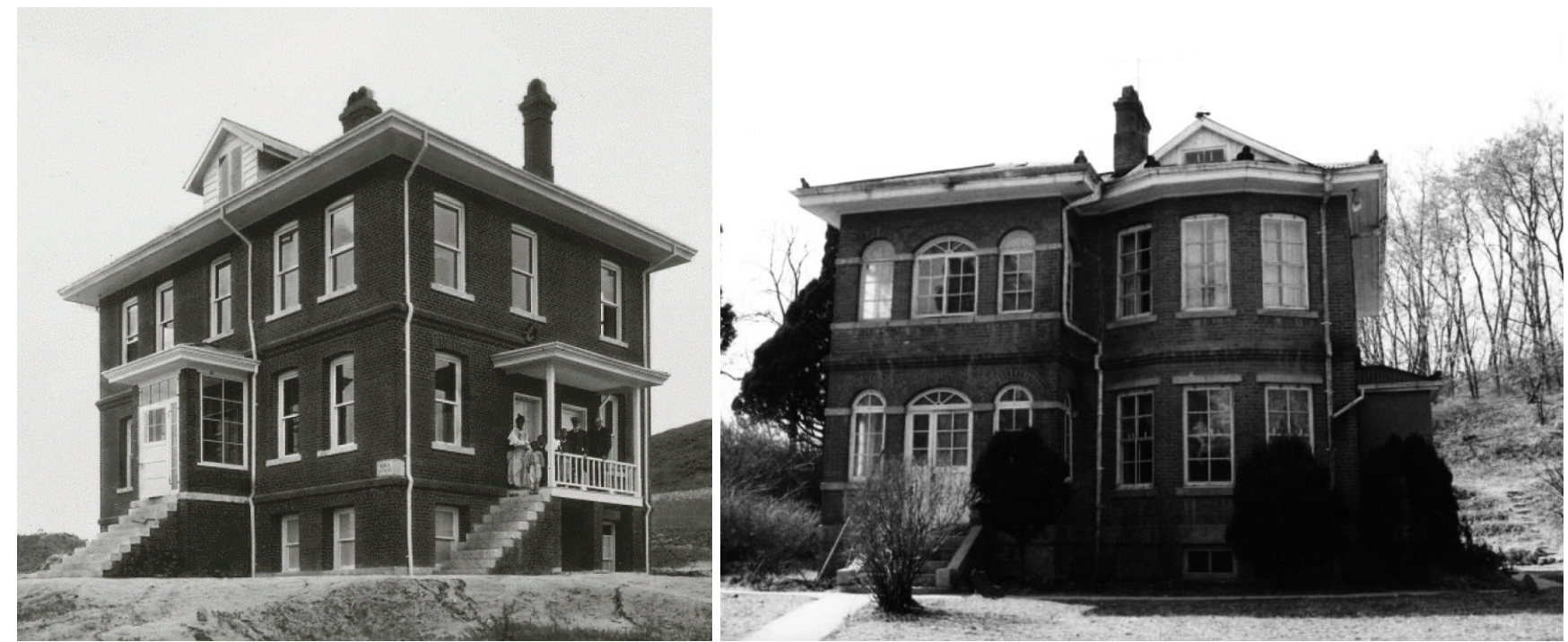

Fig. 2. Swedish Methodist Hospital (left) and house of McManis couple (right).

pital) worked as doctors in the Swedish Methodist Hospital. In particular, Ahn served the community faithfully through many different roles, including medical service to teaching as well as missionary and administrative work (Singanhoe).

McManis recorded that training the community about the importance of early treatment and basic medical knowledge had created hopeful signs; providing Korean staff members with hygiene facilities was also used as a positive example in written reports. ${ }^{4}$ Below are the health education reports in $1927^{5}$ and health education reports in $1928 .^{6}$
In the interest of Public Health, classes were held every day for a week at the time of the District Classes. At that time, a Health Clinic was provided to mothers, and various posters fully explained how to stay well. They were also taught by example on what to feed, as well as how to feed, bathe, and take care of the baby, to make sure that children's lives would not be needlessly lost (1927). ${ }^{5}$

At the time of the Men's and Women's Bible classes, which lasted 10 days each, a Korean doctor gave lectures on Baby Welfare and Public Health. These have been much appreciated. Locally, 
Sung Ku Ahn, et al.

Table 1. Treatments at Swedish Methodist Hospital

\begin{tabular}{lcccl}
\hline \multicolumn{1}{c}{ Period } & Admission & Out-patient (including visit treatment) & Operation & \multicolumn{1}{c}{ Doctor } \\
\hline Sep 1913-May 1914 & 7 & 1042 & 18 & A.G. Anderson, R.R. Reppert \\
Jun 1914-Mar 1915 & 89 & 2157 & 29 & A.G. Anderson, Y.S. Kim \\
Apr 1915-Mar 1916 & 65 & 1958 & 34 & A.G. Anderson \\
Jan 1916-Dec 1916 & 119 & 3055 & 84 & A.G. Anderson \\
Sep 1918-Sep 1919 & 221 & 4637 & 182 & A.G. Anderson, S.W. Yoon \\
Oct 1919-Sep 1920 & 227 & 5604 & 163 & S.W. Yoon \\
Sep 1922 & 87 & 3144 & - & S.W. Yoon \\
Feb 1925-Jun 1925 & - & 2487 & 12 & S.E. McManis, S.Y. Ahn \\
1927 & 41 & 7010 & - & S.E. McManis, S.Y. Ahn, E.G. Lee \\
1928 & 71 & 3657 & 74 & S.E. McManis, E.G. Lee \\
Jun 1928-May 1929 & 97 & 369 & - & E.G. Lee \\
1931-1932 & - & 800 & - & B.Y. Kim, S.O. Lee
\end{tabular}

there is an increasing demand for the doctor's services rather than the midwife, resulting in less infant mortality. Although this only marks a slight beginning, we are glad to note the dawn of a better day for mothers and babies. In this respect, we should state that our nurse usually makes several follow-up calls in which she teaches the mother how to bathe and care for the baby (1928) (Fig. 3). ${ }^{6}$

McManis' wife was a registered nurse who graduated from a nursing college in the United States. She handled the public health and infant welfare affairs in Wonju.

\section{MATERNAL AND CHILD PUBLIC HEALTH PROJECTS IN THE JOSEON PERIOD}

In January 1924, pre-liberation infant welfare work in Korea began with a mothers' group started by a Methodist women's missionary group in Gongju, South Chungcheong Province. A donation from an American philanthropist funded the construction of an infant welfare hall, which housed a doctor's office, meeting room for mother's group, and milk supply room. It became the missionary hospital at a later date. In 1930, infant life-saving stations began to be built for various services, such as pre-birth assessment, training, midwifery, and daytime and nighttime childcare. Then, in 1932, the South Chungcheong Provincial Office was relocated to Daejeon, along with the infant welfare hall and milk supply center. In addition, after combining the financial support of philanthropists from Denmark and American Methodist missionaries, a new building was built. Meanwhile, under the supervision of Samuel and M.E. McManis, the Swedish Methodist Hospital began its maternal and child health project in 1925, well in advance of similar projects in other regions. Afterward, the McManis couple (Fig. 1) became involved in similar maternal and child health projects across Korea, including a project in Pyongyang during the 1930s, another project under a missionary alliance in Seoul's
Severance Hospital in 1934, Pyongyang Union Christian Hospital child health project in 1934, the North Presbyterian Church child health project in Incheon's Naeri Church in 1935, and the Missions of the Presbyterian Church of Australia's Busan Infantorium in 1939.

\section{BRINGING GOOD NEWS WITH MEDICAL CARE}

The re-opening of the hospital meant that the missionaries now had a much better environment for their work, and that the people of the area were much more receptive to the mission. The reports written by McManis in 1926 and 1928 detail the story of a "man living 40 miles away from Wonju," who suffered severe head and hand injuries from a tiger attack. After 7 days of folk medicine treatment, his condition worsened, and he was brought into the hospital. He later recovered, returned to his home, led prayer groups, and eventually built a church in his village.

A woman suffering from severe frostbite recovered 4 weeks after receiving surgery to remove necrotic tissue. After being carried by oxen to her home, her husband met a missionary worker named Carlson (who presided over a church in Wonju-eup from 1924 to 1928). The husband learned Hangeul and went on to study the Bible as a Christian. These accounts detail how medical missions helped spread the gospel.

\section{INTRODUCING THE FIRST EVANGELIST}

Seong-seo Gu, who graduated from the Methodist Theological Seminary, originally worked in the Icheon and Yeoju areas before his failing health forced him to step down from his post in 1926. ${ }^{4}$ During his treatment in the Swedish Methodist Hospital, Gu continued to work as a missionary. After his recovery, Gu was first assigned to a church in Chungju in 1928, but was 
later assigned to Wonju in 1929. Below is a report made by McManis to the International Medical Missionary Society (March 23, 1927).

It is the non-Christians there that we especially hope to touch.

\begin{tabular}{|c|c|c|c|c|c|c|c|c|}
\hline 고 & 個 & 그 & 當 & 어 & 이 & 男 & 라 & 事 \\
\hline 祈 & 洞 & 는 & 하 & 머 & 減 & 女 & 傳 & 業 \\
\hline 禱 & 里 & 完 & 여 & 니 & 少 & 査 & 道 & 이 \\
\hline 의 & 에 & 治 & 治 & 들 & 한 & 經 & 事 & 進 \\
\hline 家 & 居 & 되 & 療 & 의 & 것 & 會 & 業 & 步 \\
\hline 族 & 住 & 여 & 하 & 게 & 이 & 가 & 까 & 된 \\
\hline 을 & 하 & 自 & 다 & 兒 & 올 & 잇 & $\begin{array}{l}\text { 지 } \\
\text { 하 }\end{array}$ & 것 \\
\hline $\begin{array}{l}\text { 세 } \\
\text { 다 }\end{array}$ & 는 & $\begin{array}{l}\text { 家 } \\
\text { 에 }\end{array}$ & 가 & 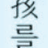 & $\begin{array}{l}\text { 세 } \\
\text { 다 }\end{array}$ & $\begin{array}{l}\text { 서 } \\
\text { 서 }\end{array}$ & 실 & 인 \\
\hline 信 & 九 & 도 & 病 & 養 & 이 & 朝 & 잇 & 로 \\
\hline 者 & 名 & 라 & 院 & 育 & 것 & 鮮 & 게 & 病 \\
\hline 가 & 의 & 간 & 을 & 하 & 이 & 醫 & 된 & 院 \\
\hline 되 & 新 & 後 & 차 & 는 & 우 & 事 & 것 & 에 \\
\hline 고 & 信 & 에 & 저 & 것 & 리 & 는 & 을 & 서 \\
\hline 會 & 者 & 하 & 왓 & 이 & 가 & 嬰 & 감 & 는 \\
\hline 堂 & 가 & 나 & 슴 & 나 & 微 & 兒 & 사 & 더 \\
\hline 까 & 病 & 님 & 으 & 沐 & 弱 & 養 & 하 & 욱 \\
\hline 지 & 院 & 께 & 로 & 浴 & 하 & 育 & 옵 & 盡 \\
\hline 建 & 에 & 感 & 入 & 식 & 나 & 法 & 나 & $\underset{=}{\text { 力 }}$ \\
\hline $\begin{array}{l}\text { 隹 } \\
\text { 하 }\end{array}$ & 서 & 謝 & 院 & 히 & 마 & 과 & ol & 한 \\
\hline 아 도 & $\frac{1}{\text { ol }}$ & 하 & 식 & 는 & 始 & 公 & 昨 & 兄 \\
\hline 록 & 病 & 自 & 고 & 을 & 한 & 衛 & 年 & 이 \\
\hline 힘 & 을 & 家 & 手 & 莜 & 것 & 生 & 中 & 외 \\
\hline 썻 & 治 & 에 & 術 & 授 & 인 & 을 & 에 & 다 \\
\hline 사 & 療 & 祈 & 後 & 하 & 데 & 敎 & 는 & 또 \\
\hline 오 & 하 & 禱 & 治 & 겟 & 압 & 授 & 特 & 米 \\
\hline 며 & 는 & 所 & 療 & 나 & 흐 & 함 & 別 & 國 \\
\hline 或 & 中 & 를 & 하 & 이 & 로 & 으 & 히 & 의 \\
\hline 은 & 에 & 定 & 기 & 다 & 모 & 로 & 惡 & 補 \\
\hline 許 & 서 & 하 & 를 & 특 & 든 & 多 & 한 & 助 \\
\hline 諾 & 作 & 고 & - & 별 & 어 & 大 & 流 & 는 \\
\hline 한 & 定 & 信 & 週 & 한 & 머 & 한 & 行 & 㫐 \\
\hline 後 & 한 & 者 & 刊 & 일 & 니 & 有 & 病 & 情 \\
\hline 에 & 섯 & 등 & 한 & 은 & 와 & 益 & 麻 & 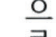 \\
\hline 린 & 며 & 싱 & 는 & 原 & $\begin{array}{l}\text { 아 } \\
=H\end{array}$ & 릅 & 族 & 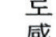 \\
\hline 가 & 4 & 將 & 하 & 州 & 에 & 도 & $\frac{0}{2}$ & 偨 \\
\hline 사난 & 느 & 贸 & 엔 & 에 & 리 & 산 & 堛 & $\begin{array}{l}\text { 먹 } \\
\text { 항 }\end{array}$ \\
\hline 람 & 午 & 禮 & 우 & 서 & 게 & ol & 하 & 루 \\
\hline 도 & $\doteq$ & 拜 & 리 & 四 & 더 & 다 & 야 & 밧 \\
\hline 잇 & 洞 & 堂 & 는 & 十 & 욱 & 그 & 苦 & 게 \\
\hline 사 & 里 & 까 & 그 & 里 & 有 & 것 & 痛 & 업 \\
\hline 오 & 에 & 지 & 의 & 밧 & 益 & 은 & 을 & 는 \\
\hline 니 & 二 & 建 & 家 & 게 & 이 & 産 & 當 & 것 \\
\hline 모 & 十 & 築 & 族 & 사 & 잇 & 婆 & 하 & 은 \\
\hline 든 & $七$ & 하 & 들 & 는 & 기 & 들 & 는 & 불 \\
\hline 結 & 回 & 기 & 의 & 사 & 를 & 이 & 이 & 샹 \\
\hline 果 & 를 & 를 & 게 & 람 & 바 & 醫 & 들 & 한 \\
\hline 는 & 巡 & 圖 & 그 & 이 & 라 & 師 & 을 & 사 \\
\hline 곳 & 廻 & 謀 & 리 & 범 & 며 & 를 & 힘 & 람 \\
\hline 알 & 하 & 하 & 스 & 을 & 伊 & 淸 & 써 & 들 \\
\hline 수 & 야 & 는 & 도 & 잡 & 後 & 하 & 도 & 의 \\
\hline 업 & 許 & 中 & 의 & 다 & 로 & 는 & 와 & 게 \\
\hline 고 & 諾 & 이 & 福 & 가 & 우 & 것 & 주 & 救 \\
\hline 오 & 한 & 외 & 音 & 頭 & 리 & 이 & 엇 & 濟 \\
\hline 직 & 信 & 다 & 을 & 部 & 看 & 나 & 스 & 하 \\
\hline 하 & 者 & 其 & 專 & 와 & 護 & 嬰 & 며 & 는 \\
\hline & 들 & 外 & 하 & 팔 & 員 & 兒 & 또 & 事 \\
\hline 님 & o & 에 & 엿 & 에 & 들 & 의 & 그 & 業 \\
\hline & 尋 & 는 & 슴 & 重 & 은 & 死 & 當 & 뿐 \\
\hline & 訪 & 十 & 니 & 傷 & 모 & 亡 & 時 & 아 \\
\hline 기 & 하 & - & 다 & 을 & 든 & 率 & 에 & \\
\hline
\end{tabular}

Fig. 3. Report on preventive medicine (1928).
Since December, we have had an Evangelist to help with this work. He has his desk in the waiting room and talks with the patients while they wait their turn to see the doctor. He gives out treats and Gospels. He has made a poster and hung it above his desk. It shows a picture of a man about to be swallowed by a serpent, illustrating the dangers of a drinking problem. The in-patients always come with their relatives and friends, and he uses that opportunity to speak to them.

We hope that you might meet the Evangelist. He is such a fine young man - a real example of Christianity. He is a secondgeneration Christian, a graduate of the Theological school, and a man with personal experience. He has a very attractive personality, and is well-received by everyone. In fact, he is often overwhelmed with invitations to preach and teach. A church service in Korea is not always as quiet as it might be, but this man is always given a quiet attention.

McManis' primary goal was medical care. However, the hospital suffered from chronic underfunding, as it had a much higher ratio of charity cases compared to other hospitals. Therefore, to keep the hospital in operation, McManis spent a considerable amount of time leading donation drives in Pyeongchang, Yeongwol, Jecheon, Munmak, and Hoengseong, as well as writing to Methodist missionaries in the United States. After all, medical missionary work and the gospel are like light and salt.

\section{EMPHASIZING THE IMPORTANCE OF EDUCATIONAL MISSIONARY WORK}

Returning to Philadelphia in 1929 for a sabbatical, ${ }^{7,8}$ McManis sent reports to headquarters in New York about the status of medical missionary work in Korea and the need for medical training (1930). ${ }^{8}$

My opinion regarding the future medical needs in Korea is essentially that of the Findings of the Association of Medical Missionaries of all Boards in Korea, namely, that the greatest emphasis should be placed upon teaching institutions (medical) in the future.

Having personally experienced the achievements and shortcomings of the medical missionary work in Joseon, McManis felt that the medical, educational, and missionary work in Korea must be handled by Korean doctors. However, his "preparations for educational projects after returning to Korea" were rejected, which perhaps killed his dream to return to Wonju. In the following poem, ${ }^{6} \mathrm{McManis}$ spoke about his 4-year experience in the Swedish Methodist Hospital (1928).

God, patient of beginning, 
Help us this day to see

Time has no real beginning, no real end-

Just continuity.

Teach us that years in passing,

Heal, pardon, make us wise.

Teach us that days, in coming bring with them

Fulfilment and surprise.

God, patient of beginnings,

Help us this day to see

In earthy bulbs, spring flowers; in man, the Christ;

In years, eternity!

\section{AUTHOR CONTRIBUTIONS}

Conceptualization: Sung Ku Ahn. Data curation: Sung Ku Ahn and Jong Won Yoon. Formal analysis: Sung Ku Ahn, Sang Baek Koh, and Solam Lee. Investigation: Sung Ku Ahn, Sang Baek Koh, and Jong Won Yoon. Project administration: Sung Ku Ahn and Sang Baek Koh. Resources: Jong Won Yoon. Supervision: Sung Ku Ahn and Sang Baek Koh. Validation: Sang Baek Koh and Solam Lee. Visualization: Sung Ku Ahn and Jong Won Yoon. Writing_original draft: Sung Ku Ahn. Writing_-review \& editing: all authors. Approval of final manuscript: all authors.

\section{ORCID iDs}

Sung Ku Ahn Sang Baek Koh

Solam Lee Jong Won Yoon https://orcid.org/0000-0003-0978-9426

https://orcid.org/0000-0001-5609-6521

https://orcid.org/0000-0001-6458-9449 https://orcid.org/0000-0001-9528-3186

\section{REFERENCES}

1. Ahn SK. 100 years of Wonju medical work. 1st ed. Seoul: Jinsol Pub; 2013. p. 72-7.

2. Ahn SK, Koh SB. Albin Garfield Anderson (1882-1971): a history of medical missionary work. Yonsei Med J 2019;60:403-6.

3. Park KS, Park YS, Yoon J, Koh SB, Ahn SK. Dr. Sa Young Ahn (1890-1968), a compassionate devotion to humanity. Yonsei Med J 2019;60:887-9.

4. McManis SE. Swedish Memorial Hospital. Methodist Episcopal Church 1926;1:247.

5. McManis SE. Swedish Memorial Hospital. Methodist Episcopal Church 1927;1:339.

6. McManis SE. Report of Swedish Memorial Hospital (Wonju). Methodist Episcopal Church 1928;1:63-4.

7. McManis SE. Swedish Memorial Hospital. Methodist Episcopal Church 1929;1:74.

8. McManis SE. Personal letter. Methodist Episcopal Church 1930;1:102. 